\title{
The Early Cartography of Japan
}

\section{Author(s): H. Yule Oldham}

Source: The Geographical Journal, Vol. 4, No. 3 (Sep., 1894), pp. 276-279

Published by: geographicalj

Stable URL: http://www.jstor.org/stable/1774244

Accessed: 27-06-2016 05:28 UTC

\section{Your use of the JSTOR archive indicates your acceptance of the Terms \& Conditions of Use, available at}

http://about.jstor.org/terms

JSTOR is a not-for-profit service that helps scholars, researchers, and students discover, use, and build upon a wide range of content in a trusted digital archive. We use information technology and tools to increase productivity and facilitate new forms of scholarship. For more information about JSTOR, please contact support@jstor.org.

The Royal Geographical Society (with the Institute of British Geographers), Wiley are collaborating with JSTOR to digitize, preserve and extend access to The Geographical Journal 
Island in the beginning of October. Up to that time the conditions had been extremely favourable, the health of the party had been excellent, and the weather continuously fine. Four days after Mr. Wellman left the ship was crushed by ice, and only some stores were saved. A message reporting the wreck overtook Mr. Wellman at Martin's Island, and he, with Mr. Dodge and two other members of the party, returned to Walden Island. A house was built with the wreckage of the ship, in which the greater part of the crew was accommodated, and on May 31 Mr. Wellman started to rejoin his party, and, according to news brought to Walden Island by Mr. Winship and a companion, the expedition was temporarily stopped by impassable ice on June 17, six miles to the east of Platen Island. On the return of Mr. Winship, Captain Bottolfsen and four men started southwards across the ice, taking the aluminium boats, and, after a journey of 230 miles, was picked up by the Malygen at Rodeleorg on July 24. On August 10, the United States Consular Agent at Tromsoe despatched Captain Bottolfsen in the Malygen to Spitzbergen, with a supply of provisions and clothing for the expedition, for which the Malygen was to search. Five days after the Malygen left, on August 15, Mr. Wellman and the remaining members of his expedition arrived at Tromsoe, all well, in the whaleboat Berentine. From the details which have come to hand, it would seem that on May 12, when the expedition had reached a point within a few miles of the 81st parallel, they were obliged to turn east, their further passage north being blocked by ice. Nearly the whole of North-east Land is stated to have been explored, and a number of interesting observations made. The expedition suffered great hardships while crossing Dove Bay, but eventually reached Walden Island, and some distance further south were taken on board by a fishing-vessel, which brought them to Tromsoe. Mr. Wellman intends, it is stated, to lead a second expedition by the Spitzbergen route next summer.

\section{GENERAL.}

Death of M. Dutreuil de Rhins.-We regret to learn of the murder in Tibet of M. Dutreuil de Rhins, the well-known French explorer. He had been travelling in Central Asia for about three years. M. Dutreuil de Rhins had in previous years travelled considerably in Africa and in the East, and was an observant explorer and competent geographer.

\section{CORRESPONDENCE.}

\section{The Early Cartography of Japan.*}

IT is now nearly six hundred years since the great Venetian traveller Marco Polo startled an incredulous Europe with wondrous tales heard on his travels, of a rich island called Chipangu, lying far out from Asia in the high seas towards the east.

The highest authority on Marco Polo-it should be unnecessary to name the classic work of the late Colonel Sir Henry Yule-accepts Polo's Chipangu as representing the Chinese Jip-păn-kwé, the kingdom of Japan, and shows that Polo's description consists of actual facts or accepted legends concerning that island.

But, according to an article, entitled " The Early Cartography of Japan," in the May number of this Journal, our accepted ideas are erroneous. "Marco Polo," says the author of this article, "writing from hearsay, describes, in my opinion, Java, and perhaps other islands contiguous to Java, under the name of Zipangu." 'The famous Fra Mauro is credited with the same interpretation of Marco Polo's intentions, in that he places next to "Giava" an island named "Zimpagu;" but

* See note on p. 270 . 
then comes Toscanelli to spoil this harmonious plan by "stealing" the name "from the proper Java, to apply it to a large island south of the equator," while the name Cipango is clapped on to the island thus robbed of its real name.

"It would be difficult," says the writer, "to find out the exact reason that urged Toscanelli to convert Fra Mauro's Giava into Cipango." It might be difficult indeed, if it had ever occurred.

Apparently Mr. Cullingridge, the author of the article in question, has allowed himself to be misled by a superficial similarity between certain maps, coupled with a misunderstanding of Marco Polo, and has placed his convictions before the readers of the Geographical Journal in so plausible a fashion that silence is impossible, lest error should spread.

Mr. Collingridge's method of investigation, as laid down by himself, is unimpeachable. "I searched," he says, "on old maps for the origin of the charting of Cipango, and I read up Marco Polo's descriptions carefully." For the first part of his investigation Mr. Collingridge justly considered Fra Mauro's map, completed in A.D. 1459, and Behaim's globe of A.D. 1492, as important documents. The former is at Venice, the latter at Nuremberg; but fortunately there are several reproductions of each in existence. For instance, among the best reproductions of Fra Mauro there is a large and on the whole faithful copy in the British Museum, there is a representation in a series of sections in Santarem's great atlas, and there are photographs, which unfortunately are in parts almost too dark to be legible, but from which a careful reproduction by Professor $\mathrm{H}$. Kiepert has been made, giving those names which are distinctly legible.

Similarly of Behaim's globe there are many copies in the various great atlases of early maps, but notably in such special works as those by Doppelmayr and Ghillany, which deal with the designer of that famous globe.

There is a third document which would be valuable if we had it, namely, 'Toscanelli's celebrated map, but that unfortunately is lost. Some details given in a letter by Toscanelli have, however, led geographers to conjecture that it must have partly formed the basis of Behaim's globe. Mr. Collingridge goes a step further in saying "we know it to be similar" to that globe, and this statement makes it the more surprising that, for the purpose of comparison in the sketch on p. 405 , Behaim's authentic globe is not used, but an attempted restoration of the lost map of 'Toscanelli.

I do not know how far Mr. Collingridge desires to assume responsibility for this sketch by signing his name to it, but it is certainly a rough reproduction of an attempted restoration of the lost map, which was originally published some years ago in "Ausland," and has been copied with tedious iteration into almost every book or atlas dealing with the period of Columbus.

It is unnecessary here to enter into a discussion of the remarkable projection employed. I need only say that it bears internal evidence, to which Professor Wagner of Göttingen first drew my attention-for instance, the extraordinary hammer-headed peninsula at the eastern extremity of Asia, which is not to be found on Behaim's globe-of having been apparently constructed from the very indifferent sketch of that globe given in Lelewel's atlas.

When placed, as on p. 405 , side by side with a greatly reduced sketch of a portion of Fra Mauro's map, an apparent resemblance is produced, which at first sight is distinctly misleading. A closer examination, however, will show that in reality this resemblance is purely superficial.

In this connexion it is, I hope, not carping criticism to protest against a certain additional similarity between the two sketches which is produced by the insertion on each of a few names, like India, Mangi, Ciampa and Zaiton, in similar types and 
at similar angles, which are not thus to be found on the originals-though, indeed, no great knowledge is required to perceive that neither Fra Mauro nor Toscanelli would have committed the error of inserting the name of Zaiton, the port, as if it were that of a province.

But I feel sure Mr. Collingridge would admit that no scientific purpose can be served by using a rough sketch of a hypothetical restoration of a lost map reconstructed from an indifferent drawing of a globe, when that globe exists and is accessible; and yet this is what has been done on p. 405. It is like quoting an author by an abridged version of a translation made from an indifferent text.

Even if the better drawing of Fra Mauro's Giava on p. 407 be compared with the "Cipango" in this Toscanelli sketch, the resemblance will be seen to be slight; but if the comparison be made with one of the careful reproductions of the original Behaim's globe, to which I have referred, the similarity will be found to be still slighter.

In fact, Behaim's Cipango, far from being "almost a tracing of Fra Mauro's Giava," resemble it only in so far as that they are both somewhat rectangular, longer than broad, and placed vertically-characteristics common to other doubtful islands in fifteenth-century maps, e.g. Antillia, Saluaga.

With regard to the sketch on p. 407 , which seems to be taken from Santarem's atlas, though it is rather startling to find in the heart of it, at the end of a long inscription beginning " Giava mazor isola noblissima," the words " Geo. Collingridge del. 93," there is certainly a superficial resemblance to Java and some of its adjacent islands; but this again is misleading, and, it must be said, much less marked in Kiepert's reproduction of Fra Mauro. It is really only due to the fact that there is a short string of small islands to the east of Java, while Fra Mauro shows Java as a large island in the middle of a string of smaller ones stretching halfway round the world. Mr. Collingridge's statement that Fra Mauro "must have drawn these East Indian islands from a portolano, for they bear, especially Java, the characteristic correct features of those documents," rests on no other basis than his own assertion. It would indeed be remarkable if Fra Mauro had had accurate information of these few islands, when it is only too evident that his knowledge of their situation and surroundings, as, in fact, of nearly the whole of Asia, both continental and insular, was of the very vaguest description. Mr. Collingridge adopted a second line of investigation-"I read up Marco Polo's descriptions carefully," he says.

It is difficult to believe that any one could nowadass set himself to write seriously about Marco Polo without consulting Colonel Yule's edition, but had Mr. Collingridge done so, it is improbable that he would have made such statements as that "the descriptions of the extraordinary richness of the sovereign's palace," etc., "have always referred to Java," or that " the great Khan Kublai may have sent military expeditions to Japan; we know for certain that he sent several to Java;" for in the edition referred to, authorities are quoted to show that the former agree with Chinese traditions about Japan, and as reards the latter point, the dates are given of more than half a dozen expeditious sent by Kublai against Japan between A.D. 1266 and A.D. 1281, together with a long extract from the Japanese Annals translated by Titsing, referring to a Mongol expedition, which agrees with that described by Marco Pulo, even down to the names of the generals in command.

It is, however, not merely Marco Polu's editor, but that grave writer himself, who fails to receive the careful consideration which is his due. According to $\mathrm{Mr}$. Collingridge, "Marco Polo says that the island of Zipangu is 1500 miles from China," and "gives precisely the same distance to Java." What Marco Polo actually says is, "You must know that on leaving the port of Zayton you sail west-south-west 1500 
miles, and then you come to a country called Chamba" (Cochin Cinina); and in the following chapter, "when you sail from Chamba 1500 miles in a course between south and south-east, you come to a great island called Java," which altogether gives the position of Java as 3000 miles in a southerly direction from the port of Zayton, in China, while "Chipangu is an island towards the east in the high seas 1500 miles distant from the continent." Mr. Collingridge seems to have skipped a chapter in his reading of Marco Polo.

It is, however, a description of the monsoon navigation which he finds "conclusive." It is only necessary to point out that this description occurs after Marco Pulo has finished with Chipangu, exclaiming, "But now we will have done with that island, and speak of something else."

These inaccuracies with regard to Marco Polo are so obrious that reference to Mr. Collingridge's article would have been needless had he not appealed to cartography, and illustrated his paper by sketches which are likely to mislead.

There is a double danger with regard to early maps, which demands great discretion in their use. Comparative cartography is a most valuable adjunct to the scientific investigator, but in unskilled hands is like a keen-edged tool, not only dangerous to the user, but apt to suffer injury itself.

Mr. Collingridge's concluding paragraph contains an essay in etymology which can scarcely be meant to be taken seriously. Without dwelling on the decided improbability, from known facts, of Sumbawa ever having been heard of until more than fifty years after Fra Mauro's time, or on the question of the correct reading of the name on Fra Mauro's map ("Zimpagu" is not that adopted by Kiepert, but Zimpangu), one can only express profound astonishment at the effort to identify Cipango with Sumbawa by the method of a " more homogeneous choice"! It was to have been hoped that this "method" had long since perished of welldeserved ridicule.

H. Yule Oliniam.

\section{GEOGRAPHICAL LITERATURE OF THE MONTH.}

\section{Additions to the Library.}

\section{By HUGH ROBERT MILL, D.Sc., Librarian, R.G.S.}

THE following abbreviations of nouns and the adjectives derived from them are employed to indicate the source of articles from other publications. Geographical names are in each case written in full :-

A. = Academy, Academie, Akademie.

Ann. = Annals, Annales, Annalen.

B. = Bulletin, Bollettino, Boletim.

Com. = Commerce, Commercial.

C. $\mathbf{R} .=$ Comptes Rendus.

Erdk $=$ Erdkunde.

G. = Geography, Geographie, Geografia.

Ges. = Gesellschaft.

I. = Institute, Institution.

J. = Journal.

M. = Mitteilungen.

Mag. = Magazine.

P. = Proceedings.

R. = Royal .

Rev. = Review, Revue, Revista.

S. = Society, Société, Selskab.

Sitzb. = Sitzungsbericht.

T. = Transactions.

V. $=$ Verein.

Verh. = Verhandlungen.

W. = Wissenschaft, and compounds.

Z. = Zeitschrift.

On account of the ambiguity of the words octavo, quarto, etc., the size of books in the list below is denoted by the length and breadth of the cover in inches to the nearest half-inch. The size of the Journal is $10 \times 6 \frac{1}{2}$.

\section{EUROPE.}

\section{Austria-Vienna.}

M.G. Ges. Wien 37 (1894) : 384-405.

Umlauft.

Die Wiener-Neustädter Canal. Von Professor Dr. Friedrich Umlauft.

This canal will be referred to in the Monthly Record. It forms the first part of a projected line of canal-communication between Vienna and the Adriatic. 